\title{
Nonparametric estimation of deformation relief
}

\author{
E. A. Alfyorova ${ }^{\dagger}$ \\ †katerina525@mail.ru \\ Tomsk Polytechnic University, 30 Lenin Ave., Tomsk, 634050, Russia
}

The present study is aimed at examining the possibilities of a nonparametric approach in evaluating the surface relief after plastic deformation. This method consists in using the graphs of functions obtained on the basis of three-dimensional topographies as a criterion for estimating the surface. An analysis of the deformation relief was carried out on nickel single crystals with different crystallographic orientations of the compression axis and faces. The samples were compressed at room temperature, the deformation relief was studied using scanning laser confocal microscopy. It is proposed to use nonparametric criteria (such as the distribution function of ordinates and autocorrelation function) to estimate the deformation relief on single crystals surfaces. Using the autocorrelation function, it is shown that the organization of shear traces in the structural elements of deformation reliefs of various types (meso- and macrobands, corrugated structures) leads to an increase of area with mutually consistent deformation. Based on the analysis of nonparametric criteria, the presence of one or several types of structural elements of the relief was identified in the deformation relief on the faces of the samples and their scale hierarchy was shown. The basic structural elements of the deformation relief are shear traces. Thus, a nonparametric (graphical) approach can be used as an additional method for studying the relief of surfaces in deformed solids.

Keywords: FCC single crystal, deformation relief, nonparametric criteria.

УДК: $531.6,53.03$

\section{Непараметрическая оценка деформационного рельефа}

\author{
Алфёрова Е.А. ${ }^{\dagger}$ \\ †katerina525@mail.ru
}

Томский политехнический университет, пр. Ленина, 30, Томск, 634050, Россия

\begin{abstract}
Настоящее исследование направлено на рассмотрение возможностей непараметрического подхода при оценке рельефа поверхности после пластической деформации. Данный метод заключается в использовании графиков функций, полученных на базе трехмерных топографий, в качестве критерия оценки поверхности. Анализ деформационного рельефа проводился на примере ГЦК монокристаллов никеля с различными вариантами кристаллографической ориентации оси сжатия и боковых граней. Образцы подвергались деформации сжатием при комнатной температуре, деформационный рельеф снимался при помощи сканирующей лазерной конфокальной микроскопии. В данной работе предлагается использовать непараметрические критерии (такие как функция плотности распределения ординат и автокорреляционная функция) для оценки и описания картины деформационного рельефа на поверхностях. Установлено, что для различных типов структурных элементов деформационного рельефа характерны свои оригинальные типы графиков функций плотности распределения ординат. С помощью автокорреляционной функции на примере ГЦК монокристаллов никеля показано, что организация следов сдвига в структурные элементы деформационного рельефа различного типа (мезо- и макрополосы, гофрированные структуры или складки) способствует увеличению размера области со взаимосогласованной деформацией. Кроме того, на основе анализа непараметрических критериев удалось идентифицировать наличие одного или нескольких типов структурных элементов рельефа на гранях монокристаллических образцов и показать их масштабную иерархию. При этом исходным или базовым структурным элементом деформационного рельефа являются следы сдвига. Таким образом, непараметрический (графический) подход может быть использован в качестве дополнительного инструмента при изучении рельефа поверхности деформированного тела.
\end{abstract}

Ключевые слова: ГЦК монокристаллы, деформационный рельеф, непараметрические критерии. 


\section{Introduction}

The morphology of surfaces of metals, thin films, and machine elements is studied using various methods. In the case of machine elements, of a main interest are the parameters of roughness in terms of performance parameters. In the case of analysis of the surface morphology after strain the object of study is the deformation relief, which is a reflection of the internal processes that have occurred in the crystal.

For an evaluation and control of surfaces, normalized parameters of roughness are used. There are a number of standards that regulate methods for estimating the microgeometry of the surface layer. These are standards of the International Organization for Standardization (ISO) and regional and national standards developed on their basis. Description of the surface morphology is possible through the use of 2D parameters standardized by ISO 4287:1997. However, these parameters estimate only selected regions of a surface. Even though they provide certain numeric information, they do not fully describe the morphology of the entire surface. A more detailed picture of the deformation relief can be achieved, if estimation covers not a selected area but a whole surface occupied by some type of relief. This is possible through the use of $3 \mathrm{D}$ parameters standardized in ISO 25178-2:2012. This kind of estimation seems more reliable. Even of a greater interest is the use of graphs of various functions as criteria of estimation of the deformation relief [1-3]. However, the use of different roughness parameters does not always give an unambiguous description of the surface microgeometry $[2,4,5]$. In connection with this, a nonparametric approach to estimating the surface was proposed in [6]. This approach suggests the use of such nonparametric criteria as a distribution functions of ordinates and/or of the tangents of profile tilt angles. These functions contain not less than $95 \%$ of the profile information, therefore, each such function describes only one original type of a surface microrelief with a high reliability. As opposed to the parametric criteria, the graphic (nonparametric) criteria contain more detailed information about the surface. It stands to reason that each of them is used in its own field of application. Graphs of distribution functions of ordinates have a great information value making it possible to estimate the presence and nature of protrusions and cavities on the surface. Autocorrelation function graphs enable one to measure a local region with a mutually consistent deformation (correlation radius). From the value of correlation radius, one can infer the self-organizing ability of each type of structural elements of deformation relief (SEDR) to dissipate the loading energy. A simultaneous analysis of these function graphs and 3D surface mapping would provide the most detailed information on the deformation structure.

In materials science research the deformation relief is also used in estimating the value of the inhomogeneity of deformation in single- and polycrystals [7-9].

Various methods can be used in order to describe and estimate the deformation relief formed on crystal surfaces. Beginning with the early works of Mader, Kronmüller, Pfaff, Mitchell, and Honeycombe [10], a direct measurement of slip lines is used to analyze the deformation processes that have passed through the crystal. This method is also used at present $[11-16]$. The measurement of the shear step value and the distance between traces is often used for this purpose [17]. However, the shear step value may not always be correctly determined due to some methodological problems. The difficulty in identifying the shear step value is associated with a macroscopic change of the surface shape. In turn, the change of the surface shape can change the shear amount in the area under consideration due to shear in parallel slip planes. Consequently, the obtained shear value can lead to an incorrect assessment of the physical process. Furthermore, due to the crystallography of single crystals, the deformation relief can be formed by a joint shear in one or several slip systems that sometimes makes it impossible to separate them along the profile.

This paper will focus on describing the deformation relief of various types through the use of nonparametric criteria for an example of nickel single crystals.

\section{Material and methods}

This paper describes the findings obtained on nickel single crystals with orientations of the compression axis near the corners of a standard stereographic triangle with various sets of sides. Deformation of nickel at room temperature occurs in octahedral slip planes and does not tend to form twins. This makes nickel an advantageous model material for the study of deformation structures formed on the crystal surface due to slip during deformation.

In the present study, nickel single crystals (impurities less than $0.01 \%$ ) were grown by the Bridgman method. The specimens had a shape of a tetragonal prism with a height-towidth ratio equal to two.

The single crystals' orientations have been controlled by IRIS $3 \mathrm{X}$-ray generator equipment using Laue back-reflection photographs with $\mathrm{a} \pm 1^{\circ}$ accuracy, and by further adjustment of orientation to a $\pm 0.02^{\circ}$ accuracy, using a DRON-3 X-ray diffractometer. The surface of the specimens was prepared by mechanical grinding and polishing and final electrolytic polishing in a saturated solution of chromic anhydride in ortho-phosphoric acid at $20 \mathrm{~V}$ voltage.

Compression deformation was carried out on an Instron ElektroPuls E10000 testing machine at a speed of $1.4 \times 10^{-3} \mathrm{~s}^{-1}$ at room temperature. A Leica DM 2500P optical microscope and an Olympus LEXT OLS4100 confocal laser scanning microscope were used for analyzing the deformation relief pattern. The size of the scanned section in each individual case was $0.066 \mathrm{~mm}^{2}(0.256 \times 0.256 \mathrm{~mm})$. The depth resolution is $0.06 \mu \mathrm{m}$.

\section{Experimental results}

The main structural elements of the deformation relief (SEDR) of nickel single crystals are shear traces, meso- and macrobands and corrugated (folded) structures of various types. The type of a SEDR depends on the crystallographic orientation of the single crystal. The elementary element of the deformation relief is the slip trace. It is formed by a shear in the slip plane. Several slip traces form a slip band, which can be observed with optical magnification. Slip traces and slip bands are observed at the initial stage of deformation 
for all crystallographic orientations of the single crystal. Mesobands are typical for single crystals with a compression axis [110]. Macrobands are observed in [111] single crystals, their dimensions are comparable with the dimensions of the sample. The formation of corrugated (folded) structures of different morphologies is also characteristic for this orientation. A variant of their classification according to various morphological features is given, for example, in [9].

Earlier, we established that a common feature of all SEDRs consisted in the formation of a quasiperiodic surface profile and presence of single shear steps on the profile [14]. Moreover, the formation of meso-, macrobands and corrugated structures occurs by means of shear traces selforganized in a certain manner in local points. This is well illustrated by the surface profile within these deformation structures. At the same time, each of the considered types of SEDRs forms its own specific surface morphology. This can be assessed most clearly using nonparametric characteristics of the surface roughness.

Fig. 1 shows the frequency distribution of the profile ordinates (heights) for various SEDRs. It is quite obvious that each type of deformation structures is characterized by its own distribution. Shear traces make up the basic structural element of deformation relief. The graph of distribution function of ordinates is close to the normal distribution law. The extremum of function is not shifted to the right or left, the graph is moderately extended in height. This makes it possible to describe the shear traces as an element of the relief that is characterized by short irregularities with rounded peaks.
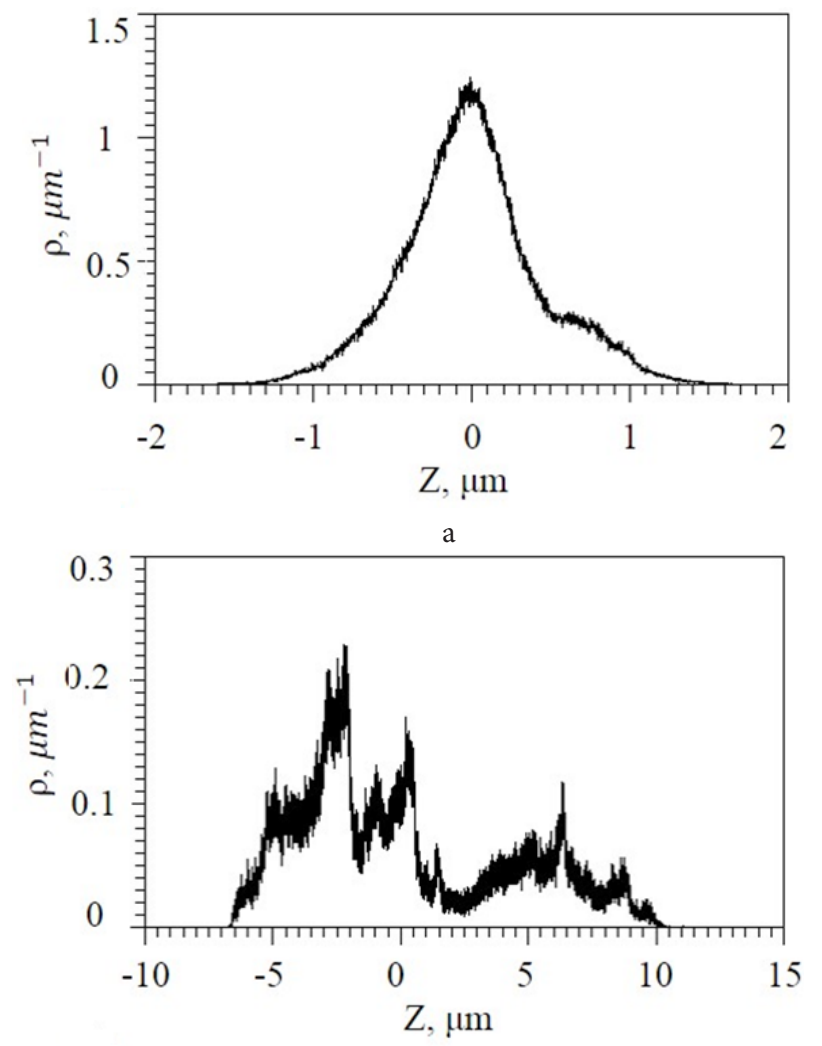

c
In this case, the root-mean-square height of the scale limited surface $(S q)$ is $0.4 \mu \mathrm{m}$. Here and further, the analysis covered the surface area of $67.4 \times 10^{-3} \mathrm{~mm}^{2}$ (ISO 25178-2:2012). For mesoscopic bands, one can observe a left shift of the extremum and the formation of a right "tail" on the graph; this means that the peaks occupy most area of the surface, in contrast to the surface occupied by the shear traces.

Mesobands are the areas of the material extrusion. The right "tail" also indicates on the presence of an additional SEDR on the surface, apart from the mesobands. These are separate shear traces, which develop between the mesobands. In this case, parameter $S q$ is equal to $0.5 \mathrm{~mm}$. For the macrobands of deformation, the graph of distribution function of ordinates has a more complicated character. The four extrema of the function indicate on the existence of several types of SEDR on the surface and suggest a hierarchical arrangement of the relief formations.

Analyzing the 3D map of the surface occupied by the macrobands (Fig. 2), one can distinguish several types of SEDRs of different scales (Fig. 2b,2c), which are reflected in the distribution function of ordinates. The value of the parameter $S q$ for the macrobands is $4.1 \mathrm{~mm}$.

As mentioned above, the corrugated structures are very diverse. Their morphology depends on the type of material, the crystallographic orientation of the sample and the site of formation [9]. There are results obtained only for one type of corrugated structures (folds) formed in the centre of the lateral face (112) of a [111] single crystal of nickel. Their morphology and profile are shown in Fig. 3. The graph of
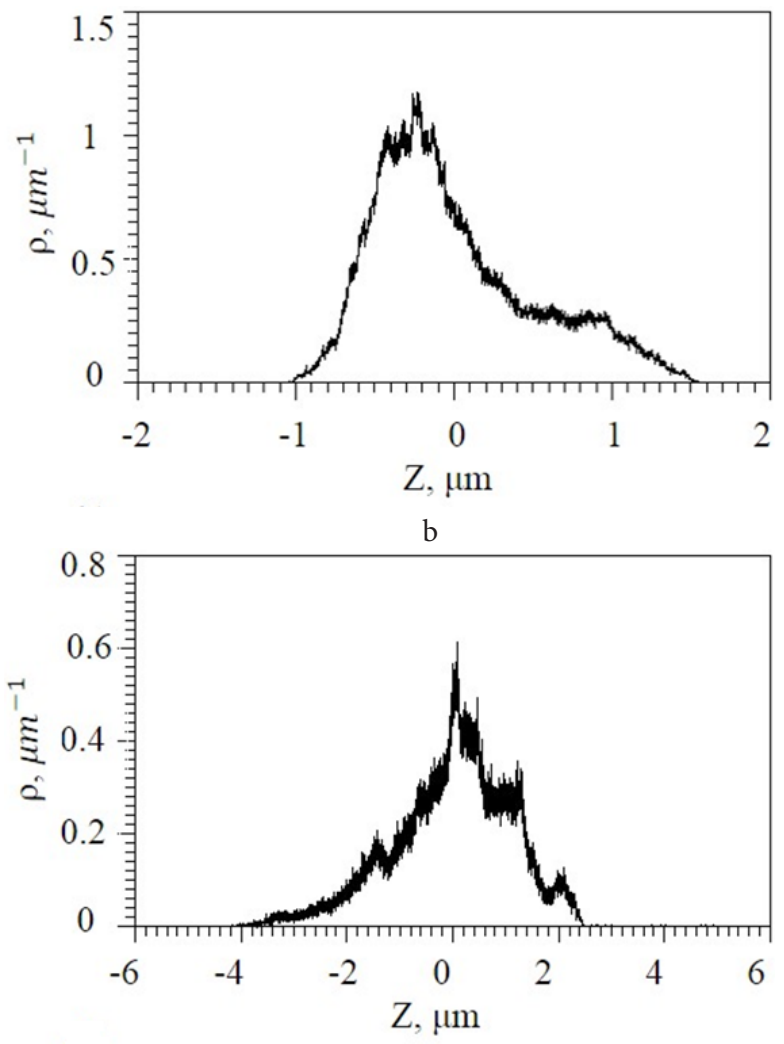

d

Fig. 1. Graph of distribution function of ordinates: shear traces $e=0.20$, [001]-single crystals (a), mesobands $e=0.22$, [110]-single crystals (b), macrobands $e=0.18$, [111]-single crystals (c), folds (corrugations) $e=0.18,[111]$-single crystals (d). 


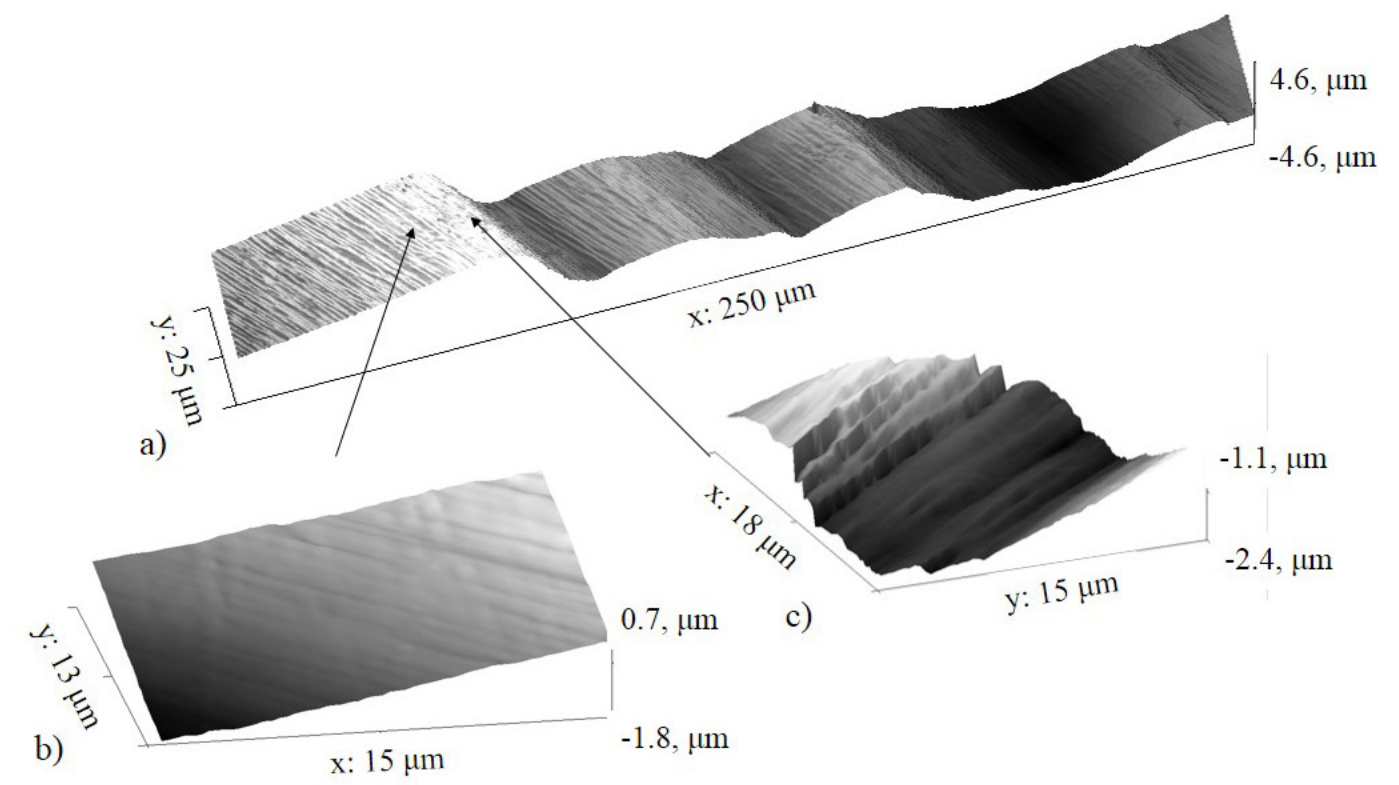

Fig. 2. Morphology of macroband forming structures: macroband system (a), on the ascent (b), on the ledge (c); figures (b) and (c) are rotated, [111]-single crystals.

distribution function of ordinates (Fig. 1d) shows quite clearly a central peak, which corresponds to the shear traces. They are clearly visible on the 3D image of the folds in Fig. 3, while the shear steps are identified on the cross section of the profile along line 3-4. At the same time, the distribution function exhibites a number of additional peaks, which are not so pronounced and belong to shear traces with different degrees of development and directly to corrugations. The corrugated structure (folds) forms the left "tail" of the distribution and a shorter curve of the ordinate distribution density as compared to the shear trace curve. All these features testify that there are acute cavities on the surface (Fig. 3). The value of the parameter $S q$ is $1.1 \mathrm{~mm}$ in this case.

Thus, taking the shear traces as basic SEDRs and their ordinates distribution function graph as the initial one, one can conclude that the mesobands are SEDRs morphologically closest to the shear traces. Mesobands are characterized by low rounded projections and a large number of cavities on the surface. Macrobands are specifically organized shear traces with varying degrees of development. The studies carried out by the authors with the use of EBSD analysis, have shown that formation of macrobands activates a mechanism that is supplementary to the dislocation sliding, and also referred to as the disorientation of local near-surface regions [18].

The use of the autocorrelation function allows one to infer the interaction of local regions, while the correlation radius $r_{k}$ shows the size of the region with a self-consistent deformation. The correlation radii for various types of SEDR are: $37 \pm 9 \mu \mathrm{m}$ (shear traces), $42 \pm 8 \mu \mathrm{m}$ (mesobands), $43 \pm 5 \mu \mathrm{m}$ (macrobands), $60 \pm 6 \mu \mathrm{m}$ (corrugations, folds). All of the above makes it clear that the organization of shear traces in various types of SEDRs ultimately enlarges the region with a mutually consistent deformation. This facilitates maintaining the integrity of the crystal under loading and contributes to a more heterogeneous deformation.

Thus, it can be concluded that each type of SEDR is characterized by its own nonparametric characteristics. As the extent of the SEDR increases, the region with self-consistent
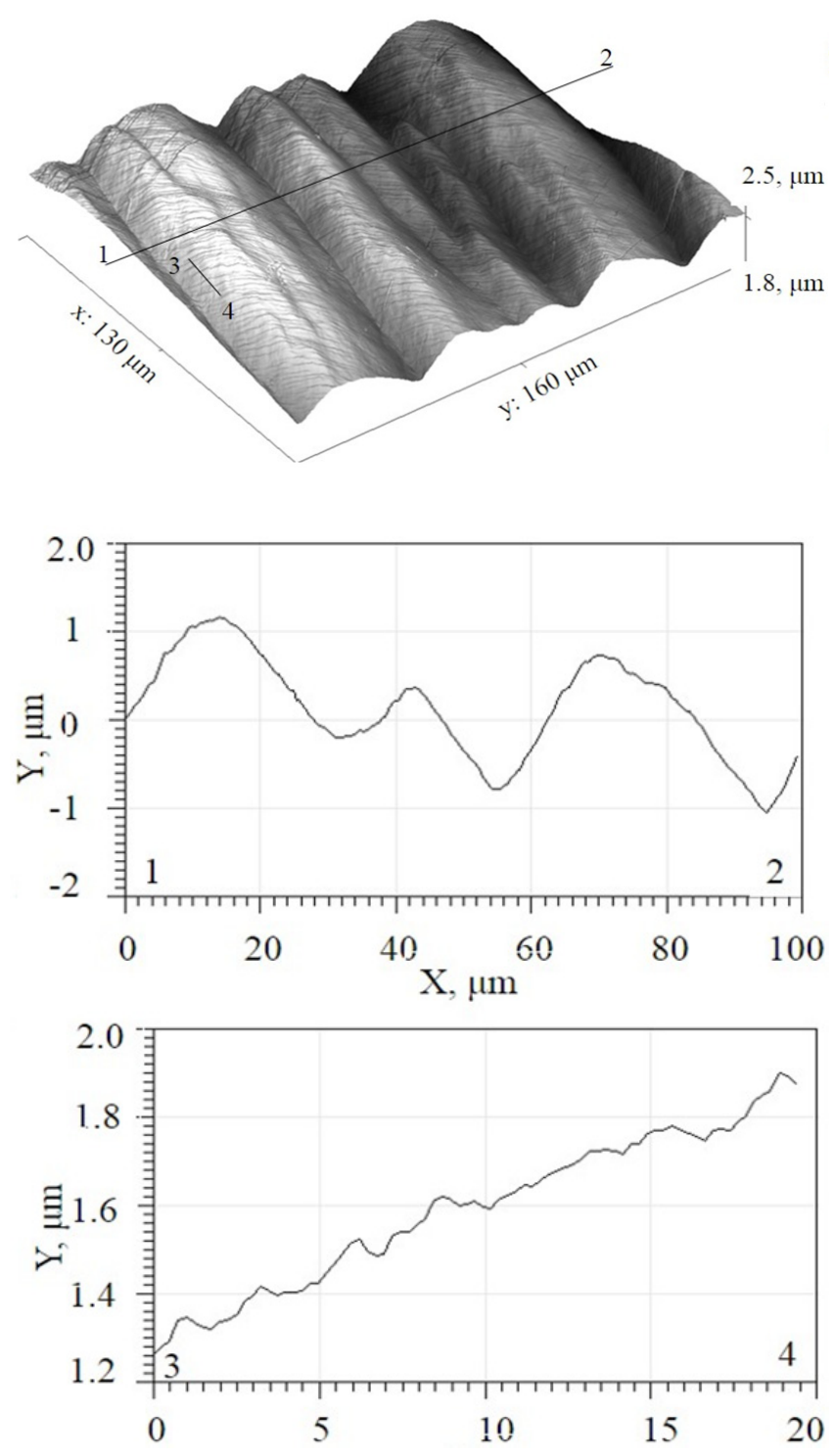

Fig. 3. 3D image of a folded structure (corrugations) and surface profiles along the secants? [111]-single crystals. 
deformation becomes larger as well as the root-mean-square value of the height, i.e. the relief development provides a dissipation of the loading energy. Based on the graph of distribution function of ordinates, one can identify one or several types of structural elements within the deformation relief. They are also indicative of a large scale hierarchy in the deformation relief. At the same time, the initial (basic) SEDR are the shear traces.

The results presented show that the analysis of nonparametric roughness criteria makes it possible to identify one or several types of structural elements of the deformation relief and to show their large scale hierarchy.

Aknowledgements. In conclusion, the author express their gratitude to A.V. Philippov for his assistance in obtaining experimental results and Professor D. V. Lychagin. The reported study was funded by RFBR, according to the research project No.16-32-60007 mol_a_dk.

\section{References}

1. V.K. Belov, D. O. Begletsov, E. V. Gubarev, S. V. Denisov, M.V. Dyakova, K.V. Smirnov. The Bulletin of the Bauman Moscow State Technical University G. I. Nosov. 1, 73 (2014). (in Russian) [В.К. Белов, Д. О. Беглецов, Е.В. Губарев, С.В. Денисов, М.В. Дьякова, К.В. Смирнов. Вестник МГТУ им. Г.И. Носова. 1, 73 (2014).]

2. V.A. Valetov, A. Yu. Ivanov. Metallobrabotka. 6, 55 (2010). (in Russian) [В.А. Валетов, А.Ю. Иванов. Металлообработка. 6, 55 (2010).]

3. S.S. Dyachenko, I.V. Ponamarenko. Progressive technologies and machine-building systems. 1, 128 (2014). (in Russian) [C.С. Дьяченко, И.В. Понамаренко. Прогрессивные технологии и системы машиностроения. 1, 128 (2014).]

4. V.M. Medunetsky, S.D. Vasilkov. Izvestiya vysshikh uchebnykh zavedeniy. Priborostroenie. 59, 231 (2016). (in Russian) [В.M. Медунецкий, С.Д. Васильков. Известия вузов. Приборостроение. 59, 231 (2016).] DOI: 10.17586/0021-3454-2016-59-3-231-236
5. E. A. Filimonova, O.S. Yulmetova, S.D. Tretyakov. Izvestiya vysshikh uchebnykh zavedeniy. Priborostroenie. 57, 58 (2014). (in Russian) [Е. А Филимонова, О.С. Юльметова, С.Д. Третьякова. Известия вузов. Приборостроение. 57, 58 (2014).]

6. M. Cai, S. C. Langford, J. Thomas Dickinson. Acta Mater. 56, 5938 (2008). DOI: 10.1016/j.actamat.2008.08.015

7. K.S. Chan, J.W. Tian, B. Yang, P. K. Liaw. Metall. Mater. Trans. A Phys. Metall. Mater. Sci. 40, 2545 (2009). DOI: 10.1007/s11661-009-9980-4

8. D.S. H. Charrier, J. Bonneville, C. Coupeau, Y. Nahas. Scr. Mater. 66, 475 (2012). DOI: 10.1016/j.scriptamat.2011.12.019

9. P. Franciosi, L. T. Le, G. Monnet, C. Kahloun, M.H. Chavanne. Int. J. Plast. 65, 226 (2015). DOI: 10.1016/j.ijplas.2014.09.008

10. H. S Ho, M. Risbet, X. Feaugas, G. Moulin. Scr. Mater. 65, 998 (2011). DOI: 10.1016/j.scriptamat.2011.09.001

11. R. Honeycombe. The plastic deformation of metals. London, Edward Arnold Am. Soc. Met. (1984) 483 p.

12. C. Kahloun, G. Monnet, S. Queyreau, L. T. Le, P. Franciosi. Int. J. Plast. 84, 277 (2016). DOI: $10.1016 /$ j.ijplas.2016.06.002

13. D.E. Kramer, M.F. Savage, L.E. Levine. Acta Mater. 53, 4655 (2005). DOI: 10.1016/j.actamat.2005.06.019

14. D. V. Lychagin, E. A. Alfyorova Phys. Solid State. 59, 1433 (2017). DOI: 10.1134/S1063783417070137

15. D. V. Lychagin, E. A. Alfyorova, V.A. Starenchenko. Phys. Mesomech. 14, $66 \quad$ (2011). DOI: $10.1016 /$ j.physme.2011.04.009

16. K. R. Magid, J. N. Florando, D. H. Lassila, M. M. LeBlanc, N. Tamura, J.W. Morris. Philosophical Magazine. 89(1), 77 (2009). DOI: 10.1080/14786430802558577

17. X.G. Wang, J.F. Witz, EI.A. Bartali, A. Oudriss, R. Seghir, P. Dufrinoy. Exp. Mech. 56, 1155 (2016). DOI: $10.1007 /$ s11340-016-0159-9

18. E. A. Alfyorova, D.V. Lychagin. Vector of science of Togliatti State University. 3(41), 128 (2017). (in Russian) [Е.А. Алфёрова, Д.В. Лычагин. Вектор науки Тольяттинского государственного университета. 3(41), 128 (2017).] 